\title{
Analyzing Gender Disparities in the Labour Market in an Urbanizing City- Maseru, Lesotho
}

\author{
Keneuoe Anacletta Mots'oene \\ National University of Lesotho, Lesotho \\ k_motsoene@yahoo.co.uk
}

\begin{abstract}
The study aimed at investigating the gender differences in the labour market of the urban formal sector in Maseru. The research was undertaken to illustrate the existing gender gap between men and women both in occupation and remuneration thus exposing inequality manifestations particularly in an urbanizing city, Maseru. The assessment was carried out in Maseru urban formal sector in three government entities: the National Manpower Development Secretariat, Office of the Auditor General and Ministry of Labour. The three government entities were purposively selected because of easy access of documented data and availability of resource persons to assist during data collection exercise. While at the same time a few interviews were conducted with men working in the taxi industry and the informal sector. Observations as well formed part of approach to the study to ascertain the validity of information obtained from the documented data and interviews. The main finding of the paper is that women in Lesotho the paper concludes that the formal labour market in Maseru is characterized by gender gaps where women occupy well salaried positions as opposed to their male counterparts with these low income jobs thus making men live in vicious cycle of poverty.
\end{abstract}

Keywords: Labour market, gender disparities, formal sector, urbanizing city, well-salaried positions

\section{An Overview of Gender Dynamics and Education in Lesotho}

Gender dynamics in Maseru are better understood within the history and development of the country. The colonial epoch best illustrates how modern institutions played a role in widening the gap between a male and female child within Basotho society, which better explains the origins of the current disparities in the labour market of Lesotho particularly, Maseru, the capital city. During the colonial era, gender disparities became visible with the introduction of modern education. The Paris Evangelical Mission opened a few schools in 1893. However, the strict church rules and discipline at the mission schools deterred many parents from sending their children to schools (Ambrose, 1993). The main inhibiting factor was the cultural values of the Basotho. As part of culture male children had to engage in initiation, which was not acceptable according to the religious values of Christian churches, hence restraining boys from getting education. After initiation, they were believed to be grown up and aspired to mining employment imitating their elders, thus giving less value to formal education. This education, meant for creating Christian elite, excluded the majority of the people who adhered to traditional belief systems. Again, primary education offered throughout most of the colonial epoch was targeted at producing helpers, half teachers and half evangelists (GOL Report, 1982). This was typical of colonial Africa, as Rodney (1982, p.250) noted, 'education was limited to producing only clerks and messengers'. Later, in 1940, government constructed a few schools in Maseru, the capital town, to allow Basotho higher education (Ambrose, 1993). These schools were only for the elite not for ordinary poor Basotho who only acquired their education through schools run by churches.

After independence churches in Lesotho continued to play a prominent role by providing services such as education as the state could not adequately provide these services. To date, churches and private individuals own almost 80 percent of the schools and the government owns 20 percent (Atema et al., 2004). Since 2006, primary education has been free while subsidization of secondary education commenced in 2007 . However, there are concerns about lack of adequate capacity to accommodate all primary graduates, as there are fewer secondary schools than there are primary schools (Maleleka, 2009). It is estimated that Lesotho has 1, 249 primary schools and more than 60 secondary schools. The primary enrolment is 374, 628 of the total enrolment which is 67 percent, secondary is 68,132 which is 31 percent and higher level (tertiary) is 4, 614 which is 2 percent. Female enrolment rate is high at 57 percent at primary, 36 percent at secondary and 3 percent at higher level (World Bank, 2009). There are several challenges regarding the male population enrolment in Lesotho. The process of learning has been more difficult for male children of Lesotho when fathers are part of the migrant labour system and spend long periods in the mines of RSA and the mothers have to take more responsibility than usual. With fathers gone, a new tension with lasting effects on the 
academic progress of male children is there. The male children exhibit negative attitudes toward learning. The absence of fathers could be part of the problem behind the high dropout rate and the relatively small number of children who go beyond primary level (Cranmer and Woolston, 1980).

Approximately 25 percent of children do not attend school particularly in rural areas where families are involved in subsistence activities. In many cases, families cannot afford the cost associated with attendance. Uniforms, books and other educational materials are beyond the means of many families where family stress, poverty, the spread of HIV/AIDS and divorce have led to a rise in child homelessness and abandonment, creating growing numbers of street children. Boys are more affected by nonattendance than girls. Again, in traditional Basotho society, livestock herding by young boys is a rite of passage and prerequisite to manhood in community. In the absence of fathers, boys are exposed to this heavy burden to tend flocks all day for months at the very young age of twelve, sometimes even for a yearly or monthly payment either in cash or in kind (Cranmer and Woolston, 1980).The enrolment in tertiary institutions also indicate a greater number of females versus males particularly, the National University of Lesotho which for many years have been the only university in the country (Table 1).

Table 1: NUL Undergraduate Student Population by Sex, Full-time (1996/97- 2015/16)

\begin{tabular}{llll}
\hline Year & Male & Female & Total \\
\hline $1995 / 96$ & 882 & 973 & 1855 \\
$1996 / 97$ & 947 & 1101 & 2048 \\
$1997 / 98$ & 959 & 1159 & 2118 \\
$1998 / 99$ & 1004 & 1204 & 2208 \\
$1999 / 00$ & 1142 & 1329 & 2471 \\
$2000 / 01$ & 1289 & 1523 & 2812 \\
$2001 / 02$ & 1503 & 1664 & 3167 \\
$2002 / 03$ & 1989 & 2078 & 4067 \\
$2003 / 04$ & 2221 & 2544 & 4765 \\
$2004 / 05$ & 2439 & 2701 & 5140 \\
$2005 / 06$ & 2838 & 3083 & 5921 \\
$2006 / 07$ & 3247 & 3477 & 6724 \\
$2007 / 08$ & 3473 & 3874 & 7347 \\
$2008 / 09$ & 3613 & 4148 & 7761 \\
$2009 / 10$ & 3650 & 4399 & 8049 \\
$2010 / 11$ & 3718 & 4465 & 8183 \\
$2011 / 12$ & 3291 & 4160 & 7451 \\
$2012 / 13$ & 2654 & 3786 & 6440 \\
$2013 / 14$ & 2548 & 3672 & 6220 \\
$2014 / 15$ & 2430 & 3705 & 6135 \\
\hline
\end{tabular}

Source: NUL Statistics Office, 2016

Statement of the Problem: The prevailing gender gap in Lesotho cannot easily be narrowed for the fact that the country still has male children who are not attending school because they tend herds. These boys spend time in the remote areas without any opportunity to learn through formal education system mechanisms created. On the other hand, female children are given chance to go to school and are well supported by their families. This situation has spillover effects to the labour market where there are also marked gender differences between males and females both in terms of occupation and remuneration one gets. This observably exists in the formal sector of the rapidly urbanizing city, Maseru. This paper therefore assesses the extent of this gender gap by examining the occupation and remuneration between males and females in the public sector of Lesotho

Research Objectives: The study aimed at fulfilling the following objectives:

- To ascertain whether there is a gender gap between males and females in the labour market in Maseru

- To establish the manifestations of these gender differences 
In line with these overarching objectives, the research questions are:

- How does the labour market position of women in the public sector compare with that of men?

- Are there alternative mechanisms developed by those suffering consequential to the existing gender gap?

Significance of the Study: It was worth conducting this type of investigation to illustrate that while the equality has been advocated for worldwide by various organizations and governments including the United Nations, some segments of society are still marginalized. This being the case, other sectors including the public sector as well reflects the deficiencies mainly due to the cultural and historical developmental experiences. Many studies in Lesotho have focused on other aspects of gender but not on how education relates to the gender gap in the labour market. Hence why this study was worth undertaking.

\section{Literature Review}

This section is divided into two sections. First is the debate on gender disparities in the labour market in the African cities' context where Maseru, the capital city of Lesotho belongs. Second, is the theoretical framework which informs the current study explaining how gender disparities in the labour market can emerge? In the 1980s and early 1990s, labour force growth was substantially higher for women than for men for every region of the world except Africa (Lin, 2016).Some studies done focused on specific African countries marked by huge gender disparities between men and women in the labour market, such as Mali and Botswana (African Development Bank, 2015 and Robles, 2012). A recent study, conducted by the Bank in Botswana shows that men were more advantaged in securing well-paying employment opportunities than women. The study revealed that men have an up to 44 percent advantage over women in paid employment. Women are more likely to be hired in low-paying clerical jobs or as unpaid family workers in Botswana. This effect is more pronounced in cities, towns and urban villages. Men are also twice as likely as women to be employed in professional job categories. Similarly, in Bamako, Mali's capital, 30 percent of men were employed as salaried workers compared to women at 14 percent. Paid employment offers limited opportunities to women in Uganda. Only one in ten women in Uganda is in paid employment according to the 2008 Gender Productivity Survey (Kasirye, 2011).

While this position may be shared by many other countries in Africa, in the recent times women have increased their share of the labour force; the increasing participation of women in paid work has been driving employment trends and the gender gaps in labour force participation. Lesotho to a greater extent differs with other African countries like those mentioned earlier in that women are more at an advantage than men in the labour market as this paper argues (Field Survey, 2016).Several factors have contributed to this. The cultural practices of Basotho as a nation influenced parents' decisions to send a child to school combined with the history of Lesotho that served as a labour reserve for the South African economy requiring male labour force to migrateled to prioritizing a female child over a male child (Cranmer and Woolston, 1980 and GOL Report, 1982), thus creating this gender gap. The preceding section on gender dynamics in Lesotho better exposed reasons for this scenario.

Theoretical Approach: It is imperative to illustrate that gender gap in the labour market cannot just be ignored for a number of reasons. The first reason is that there is a need to understand how two different sexes spread within occupations in organizations and how these can affect remuneration which normally translates into one's welfare through income. In order to understand this, one adopted some theories which explain the relationship between gender and labour market, how one sex may seem to be more dominant in the employment sector. Such theories are the 'horizontal and vertical sex segregation' and the 'dual labour market approach'.

Horizontal and vertical segregation: The differences exhibited by men and women in the labour market can be explained by the horizontal and vertical sex segregation. Horizontal sex segregation refers to the fact that women's employment tends to be crowded into particular sectors and occupations in the labour market, unlike the pattern of male employment, where there is a much more even spread. A number of studies used this approach. For example, Muzvidziwa and Seotsanyana (2002) observed that in the UK in 2003 there were 
more than twice as many women than men in administrative and secretarial, personal service and sales and customer service occupations Vertical sex segregation, as opposed to horizontal sex segregation, reflects the under-representation of women in higher levels of all organizational hierarchies and occupations, in particular the lack of women in higher management roles in the UK. This approach is relevant in this study context in assisting to unpack the reality in relation to the spread of men and women in the labour market of Maseru, a rapidly urbanizing city.

Dual labour market approach: The dual labour market approach helps to explain the occupational distribution of men and women by considering factors that lead to such distribution within different sectors of the economy. Such factors include training required to occupy a certain occupation which eventually make these occupations female or male dominated. For instance, there are female occupations which require specific training, at the same time, there are male occupations requiring relatively few skills and where stability is not an important factor, such as to become a driver. This approach further uses sex segregation in explaining the segmentation of the labour market. The sex segregation of occupations within both the primary and secondary sectors has led some writers to suggest that sex also needs to be considered as one of the dimensions on which the labour market is segmented. For example, Siltanen, Jarman and Blackburn (1993) argue that the labour market is characterized by segregation. Segregation refers to the separation of the two sexes across occupations. They argue that "Segregation concerns the tendency for men and women to be employed in different occupations from each other across the entire spectrum of occupations. The relationship of women workers to men workers is its key feature $(1993, \mathrm{p} .4)$ and this cannot only be explained using economic variables. Other factors outside the economic sphere can give insights into sex inequalities in the labour market. This study also concurs with this theory in trying to give other reasons explaining the existing inequalities in the labour market of Maseru.

One widely used measure of female concentration in labour market studies is the percentage of workers in an occupation who are women; male concentration would be reflected in the percentage of all workers in an occupation who are men. The percentage of women in an occupation will partly depend on the share of the labour force which is female. The greater the female representation in the work forces the more women there are likely to be in any single occupation (Siltanen, Jarman and Blackburn, 1993). Thus in the same manner, this study also looks at the representation of women versus men in the labour market of an urbanizing city, Maseruto expose the existing gender inequalities. The study highlights why a certain sex category concentrates in different organizational occupational hierarchies in three government entities.

\section{Methodology}

This study used qualitative and quantitative approaches to expose gender disparities within the labour market of Lesotho mainly Maseru, the capital city. Furthermore, the study applied the theoretical framework to help illustrate the manifestations of the inequalities between men and women both in occupation and remuneration. The study used occupation and remuneration as parameters to illustrate gender gaps across the three entities of the public sector in the capital Maseru. Occupation here refers to the established positions while remuneration refers to the salary received by respective employees at a given position. Data displayed was gathered from three government institutions (National Manpower Development Secretariat (NMDS), Office of the Auditor General (OAG) and Ministry of Labour) to unfold the gender dynamics contained in the labour market. Total establishment of each of these entities, the number of females versus males, how they spread across various positions and the income range were considered. Various positions existing in these entities were classified into three categories: high income (senior management), middle income (middle management) and general staff (low income bracket). This categorization was adopted with the intention to understand the gender dynamics existing in these entities, whether indeed there are disparities between the two gender streams, male and female. In addition, interviews were conducted with men in the low-income bracket to ascertain factors to the differences in remuneration compared to women. About 10 of those working in the construction and taxi industry were also interviewed to establish why they could not obtain jobs in the formal sector. 


\section{Results}

Gender gap in Occupation: In Lesotho, cultural practices highly influence decisions to send children to school which in turn influence the labour market in that more of the educated group tend to get jobs in the formal sector. Those who have received less education mainly men are found in the lower echelons with low pay particularly in public service as well as in other formal sectors of the economy like construction and taxi industry. This study established that 15.7 percent of women are occupying well salaried positions in the formal sector. Only a few men of about 6.1 percent are absorbed in the well salaried positions, that is senior and middle management positions (Table 2). From the table one observes a significant number of women in the low income bracket. This is mainly because women are at an advantage to secure formal employment because they attended school. Men are already few in numbers who attended school but still many of them concentrate in the low income bracket

Table 2: Categorization of Employees in the Public Sector

\begin{tabular}{|c|c|c|c|c|c|c|c|c|}
\hline & Males & Females & $\begin{array}{l}\text { Males in } \\
\text { Senior } \\
\text { Management } \\
\text { positions }\end{array}$ & $\begin{array}{l}\text { Females in } \\
\text { Senior } \\
\text { Management } \\
\text { positions }\end{array}$ & $\begin{array}{l}\text { Males in } \\
\text { Middle } \\
\text { Management } \\
\text { positions }\end{array}$ & $\begin{array}{l}\text { Females in } \\
\text { Middle } \\
\text { Management } \\
\text { positions }\end{array}$ & $\begin{array}{l}\text { Males in } \\
\text { low } \\
\text { income } \\
\text { bracket }\end{array}$ & $\begin{array}{l}\text { Females } \\
\text { in low } \\
\text { income } \\
\text { bracket }\end{array}$ \\
\hline $\begin{array}{l}\text { Office of } \\
\text { the } \\
\text { Auditor } \\
\text { General }\end{array}$ & 44 & 166 & 2 & 7 & 11 & 26 & 31 & 123 \\
\hline $\begin{array}{l}\text { National } \\
\text { Manpower } \\
\text { Secretariat }\end{array}$ & 32 & 120 & 3 & 6 & 5 & 23 & 28 & 87 \\
\hline $\begin{array}{l}\text { Ministry of } \\
\text { Labour }\end{array}$ & 53 & 100 & 4 & 8 & 5 & 14 & 44 & 78 \\
\hline
\end{tabular}

Source: Field Survey 2016

Table 2 illustrates the existence of the vertical sex segregation as opposed to the horizontal sex segregation where across the public sector; men are fewer than women in the upper positions. For example, in the OAG, there are about $31(15.5 \%)$ females as opposed to $13(6.5 \%)$ males in the management positions. This applies also to the two other institutions where females dominate the upper occupational structures. In NMDS, there are about $29(19 \%)$ females as opposed to $8(5.3 \%)$ males in the management positions and in the Ministry of Labour there are about $22(14.4 \%)$ females as opposed to 9 (5.8\%) males in the management positions (Field Survey, 2016).The scenario differs from the UK experience of 2003 where women were fewer in this categorization of organizational hierarchies and occupations. This indicates progression of women in the labour market of the capital, Maseru unlike in other African countries where males are still dominant in these positions. There is therefore a pattern of sex segregation in the three government entities which is indicated by the spread of women versus men as depicted by the statistics in this paragraph as well as Table 2 .

Moreover, these professional positions in the case of the OAG (including auditors, accountants) require longer schooling in order for one to be in higher management roles. Many of these Basotho women have university degrees which men do not have, the position which concurs with the dual labour market approach which looks at the occupational distribution of men and women in the formal sector in relation to schooling which translates into training one has acquired that goes with the position without really looking at the sex segregationas the only factor. The dual labour market approach considers the lengthy schooling as one requirement for one to engage in a professional job category. Some of these jobs were initially male dominion particularly during colonization and recent past relying more on experience than schooling, for instance, the position of the Auditor General and deputy Auditor General. In the same manner the directorship and other senior management positions in NMDS used to be occupied by males. Today these are occupied by female incumbents. The occupation hierarchies also relate to the remuneration.

Gender gap in Remuneration: It was further established that four categories of remuneration exist in the public sector as depicted in Table 3. Data depicts that in the OAG out of 200 employees, only 44 are males and 166 are females. However, 31 males are in low income bracket while 13 in management. This means that for the fact that fewer males attended school for the reasons stated in section 2, fewer are able to occupy well 
paying positions (management) when majority of those who secured a job in the public sector cluster in lowincome positions. On the one hand, if we examine the position of women, women who are already the majority in the public sector. In the OAG again 31 are in the high income bracket (management), 123 are in low-income bracket. If we take 31 of males in low-income bracket and 31 of females in high-income bracket, the gap in remuneration between men and women is quite remarkable almost half if we consider the first stream in each range. For example, M/R365, 880.00 to $414,012.00$ of top management as compared to M/R 159, 036.00to 189, 204.00 in the first category of low-income bracket stream (Field Survey, 2016). There is greater representation of women in high-income bracket as compared to men. These marked differences in remuneration can be interpreted differently as indicating the level of welfare of each recipient. In this case, the low-income bracket will remain in vicious circle of poverty; hence, men in the labour market of Maseru suffer this setback as compared to women.

Notwithstanding, we cannot deny the fact that women remain the majority in the low-income bracket in all the three entities, mainly because they are the majority who received formal education in the country as a whole. It is apparent therefore that in responding to the employment need of its nation, the public sector has no option of not absorbing these women, hence why some will have to take the available jobs, not necessarily because they do not have enough education but simply to put them to work. This concentration of female labour force in the low-income bracket in the case of the overall public sector in Maseru does not necessarily explain the issue of gender composition of an occupation to the gender composition of overall employment. However, it illustrates why a certain gender, females in this case, turn to be over-represented in this lowincome bracket. What is important is that women in Maseru today have increased their share in the labour force and participate in paid employment. They are grabbing new frontiers in the labour market, thus increasing the gender gap even in terms of remuneration.

Table 3: Remuneration in the Public Sector

\begin{tabular}{lc}
\hline Categories & Salary Scale per annum \\
\hline Top Management & $365,880.00-414,012.00$ \\
& $291,180.00-346,212.00$ \\
Middle Management & $234,360.00-276,324.00$ \\
& $193,944.00-230,604.00$ \\
General Staff & $159,036.00-189,204.00$ \\
& $128,580.00-155,184.00$ \\
$91,188.00-105,756.00$ \\
$68,316.00-79,224.00$ \\
$42,996.00-51,060.00$ \\
$28,560.00-33,972.00$ \\
& $21,660.00-25,124.00$ \\
\hline
\end{tabular}

Source: Field Survey, 2016

The study further established factors to men occupying subservient positions in the other formal sectors of the economy like the construction and taxi industry. The main factor was lack of adequate education which pushes them to these minimal paying jobs. They claimed to earn between M/R1 000.00 per month to M/R2 000.00 (Field Survey, 2016). With the prevailing economic repercussions including inflation of 8 percent per year, this salary is unsustainable besides other problems of uncertainty of continuity in the employment as layoffs are also common depending how the employer may decide. It means that men in the labour market of Maseru, a rapidly urbanizing city are continually exposed to these dilemmas which indicate that they are susceptible to poverty than their female counterparts.

\section{Conclusion and Recommendations}

It is apparent that the labour market of Lesotho particularly the urbanizing city Maseru is characterized by disparities between males and females. This is due to cultural influences which had greater bearing on deciding to send a female child to school over a male child in the historical and political economic development context of Lesotho. As a remedial action to this disparity, one can propose a road map. Various stakeholders working towards empowering different groups in the country need to refocus on empowering 
men which in the Lesotho's context have been an ignored area since independence. More emphasis has been placed on women in the development agenda which in turn has widened the already existing gap between them and already disadvantaged men. This polarization has also translated into creating other social ills including high divorce rates in the country mainly between couples of educated women and uneducated men. Maseru is likely to have more couples divorcing since half of the total population of Lesotho of 1.2 million lives in Maseru and this population is likely to increase due to opportunities existing in Maseru including education and employment which trigger urban-rural migration.

Empowering men through educational campaigns which will encourage them to enroll in part-time programmes such as those offered by the National University of Lesotho which is offered in the evening, will eventually lead to the capability development. This will translate into them obtaining formal jobs that are sustainable unlike in construction, taxi driving and informal sector where their fate is unpredictable as it depends on factors such as the employer's willingness to keep them or the availability of capital to continue operating in the informal sector. For those who did not go beyond primary level education, there is a need to encourage them to enroll through the existing distance learning programme that would enable them to upgrade their standard of education. The Ministry of Education needs to have outreach strategies (including radio programmes) of disseminating this programmer so that the less privileged segments of the population can know its benefits. Though the proverb of Basotho states that 'Thuto boholo e ea roba'- meaning that the education you receive at an old age makes someone broken. It is however noticed that through capability building one is able to improve own's life. Though some will be receiving this education at an old age that will translate into one's welfare improvement, thus breaking the vicious circle of poverty existing today in most male-headed households in Maseru.

A New area for future research: This study has recognized other gray areas which need further investigation to unfold the magnitude of their impact on household poverty prevailing in Maseru, the capital of Lesotho. Hence, future research will be on 'Assessing the impact of divorce rate on household poverty in an urbanizing City, Maseru- Lesotho'

\section{References}

African Development Bank. (2015). Gender inequality in African Labour Markets under the spotlight in two AfBD reports. Accessed at Http://www.afdb.org/en/news-and-events/article/gender-inequality-inafrican-labour-markets-under-the-spotlight-in-two-afdb-reports-14122/ on 23 March 2016.

Ambrose, D. (1993). Maseru: An Illustrated History. Morija: Morija Museum and Archives.

Atema, J., Webster, D. \& Phakisi, T. (2004). The Making of the Lesotho National Poverty Reduction Strategy (PRS). A report prepared for DFIDSA-Lesotho. Maseru: Khalapa Development Agency.

Cranmer, D. J. \& Woolston, V. A. (1980). Southern Africa: A Study of the Educational Systems of Botswana, Lesotho, South Africa, Southwest Africa /Namibia and Swaziland with an Addendum on ZimbabweRhodesia: A Guide to the Academic Placement of Students in Educational Institutions of the United States. Washington, D.C: American Association of Collegiate Registrars and Admissions Officers.

Kasirye, I. (2011). Addressing Gender Gaps in the Ugandan Labour Market.EPRC Policy Brief. Issue No. 12, April 2011. Accessed at www.http://elibrary.acbfpact.org/acbf/collect/acbf/index /assoc/HASHf1fb.dir/doc.pdf.on 23 August 2016.

Lin, L. L. (2016). Female Labour-force Participation: Trends in Female Labour-force Participation and Fertility. Accessed at www.http://un.org/esa/population/publications/.../RevisedLIMpaper.PDF.on 23 August 2016.

Maleleka, D. (2009). The Impact of Democracy in Lesotho: Assessing political, social and economic development since the dawn of democracy. Research report 115. Centre for Policy Studies, Johannesburg, September.

Muzvidziwa, V. \& Seotsanyana, M. (2002). Continuity, Change and Growth: Lesotho's Educational System. Accessed at http://radicalpedagogy.icaap.org/content/issue4_2/01_muzvidziwa.html on 23 March 2016.

National University of Lesotho. (2016). Student Enrolment Lists. Roma: NUL Statistics Office.

Robles, P. S. (2012). Gender disparities in Africa's labour markets: An analysis of survey data from Ethiopia and Tanzania. Economies and Finances. Universite Paris-Est. 
Rodney, W. (1982). How Europe underdevelopment Africa. New York: Howard University Press.

Siltanen, J., Jarman, J. \& Blackburn, R. M. (1993). Gender Inequality in the Labour Market: Occupational Concentration and Segregation, a Manual on Methodology, Interdepartmental Project on Equality for Women in Employment, International Labour Office, Geneva.

World Bank, Development Indicators. (2009). Washington D.C: World Bank. 